\title{
Znaczenie własności rolniczej w kształtowaniu ustroju rolnego
}

\section{Treść i zakres własności rolnej w świetle Konstytucji RP}

Instytucję własności w Konstytucji traktuje się jako jedną z zasad ustrojowych o autonomicznym znaczeniu. Jednym z celów konstruowania zasad ustroju jest kształtowanie pewnych kierunków działania państwa w strefie publicznej oraz prywatnej. Takim podstawowym zadaniem państwa jest również ochrona własności, niezależnie od przyznania jednostce uprawnień o charakterze indywidualnym. W tym ujęciu ochronie własności nie służą indywidualne roszczenia obywateli, bowiem gwarancją dochowania przez państwo obowiązków względem własności są ogólne środki polityczne.

Taką konstrukcję własności przewiduje właśnie art. 21 Konstytucji, stanowiąc że „Rzeczpospolita Polska chroni własność i prawo dziedziczenia”. Umieszczenie tego artykułu wśród zasad fundamentalnych ustroju w rozdziale I ma swoje znaczenie, oznacza mianowicie zdecydowane podkreślenie wagi tego przepisu dla interpretacji pozostałych części Konstytucji. W takim również kierunku zmierza przepis art. 20 Konstytucji, nakazujący w treści prawa własności uwzględnić konieczny element społecznej gospodarki rynkowej.

W rozdziale II Konstytucji: „Wolności, prawa i obowiązki człowieka i obywatela" znajduje się art. 64. Stanowi on podstawę publicznego prawa podmiotowego, którego treścią jest gwarantowana konstytucyjnie wolność nabywania mienia, jego zachowania oraz dysponowania $\mathrm{nim}^{2}$. Dysponowanie mieniem obejmuje w szczególności rozporządzanie go w drodze dokonywania przez uprawnionego czynności prawnych inter vivos oraz mortis causa; możliwa jest także dyspozycja tego mienia (własności) w drodze prawa publicznego.

$1 \quad$ Uniwersytet Marii Curie-Skłodowskiej w Lublinie.

2 Zgodnie z art. 64 „Każdy ma prawo do własności, innych praw majątkowych oraz prawo dziedziczenia”; „Własność, inne prawa majątkowe oraz prawo dziedziczenia podlegają równej dla wszystkich ochronie prawnej”; „Własność może być ograniczona tylko w drodze ustawy i tylko w zakresie, w jakim nie narusza ona istoty prawa własności”. 
Wyliczenie w art. 64 ust.1 i 2 Konstytucji nie tylko własności, ale i innych praw majątkowych oraz prawa dziedziczenia $\mathrm{z}$ jednej strony i art. 21 ust. $1 \mathrm{z}$ drugiej skłania do stwierdzenia, że Konstytucja wyłącza możliwość pozbawienia własności, będącej najpełniejszym z praw majątkowych inter vivos oraz mortis causa poza wypadkami wskazanymi w ustawie, ale nie w żadnym akcie podustawowym.

Doceniając doniosłość zasad kształtujących demokratyczne państwo prawa, gdzie społeczna gospodarka rynkowa oparta jest na wolności działalności gospodarczej, własności prywatnej (art. 20), pełnej ochronie własności i prawie dziedziczenia (art. 21 ust. 1) podlegających równej dla wszystkich ochronie prawnej (art. 64 ust. 2), nie sposób nie dostrzec pewnej bezrefleksyjności ustawodawcy przy wprowadzaniu art. 23 Konstytucji. Zasada wolności gospodarczej stanowi wyjątek ograniczający zasadę ochrony gospodarstw rodzinnych.

Artykuł 23 zawiera wyłącznie dyspozycję o charakterze ustrojowym i bardziej przypomina deklarację polityczną, a zwłaszcza wytyczne dla organów władzy państwowej ${ }^{3}$.

\section{Wykonywanie własności rolniczej}

\subsection{Prawo korzystania z gospodarstwa rolnego}

W ujęciu cywilistycznym ,korzystanie z rzeczy” (art. 140 kc. in princ) jest atrybutem wykonywania prawa własności w ramach tzw. triady uprawnień właścicielskich (ius utendi-fruendi) obok posiadania (ius possidendi) oraz rozporządzania rzeczą (ius disponendi).

Korzystanie z rzeczy najczęściej obejmuje: prawo pobierania pożytków (naturalnych i cywilnych), prawo używania rzeczy (usus), prawo pobierania innych przychodów. Granice treści prawa własności wyznaczane są przez ustawy, społecznogospodarcze przeznaczenia praw oraz zasady współżycia społecznego.

$\mathrm{Na}$ tle cywilistycznego ujęcia treści i wykonywania prawa własności najbardziej złożony jest problem wykonywania własności rolniczej w zakresie atrybutu „,korzystania z rzeczy”. W odniesieniu do gospodarstwa rolnego chodzi bowiem o konglomerat norm prawnych, które w zasadzie regulują inne materie niż rzeczy w rozumieniu art. $45 \mathrm{w}$ zw. z art. $140 \mathrm{kc}$., a nawet w sposób tylko pośredni wpływają na prawo korzystania z rzeczy, jak np. z nieruchomości rolnej. Następuje również coraz szersza ingerencja w treść prawa własności rolniczej w ujęciu prawa krajowego na rzecz prawa wspólnotowego. 
Kodeksowa regulacja wskazująca na prawo właściciela do korzystania z rzeczy jest niewystarczająca. Chcąc dowiedzieć się, w jaki sposób rolnik może wykorzystać swoją nieruchomość rolną, a nawet szerzej ujmując - swoją ziemię - i inne składniki gospodarstwa rolnego, najczęściej musimy sięgać do przepisów pozakodeksowych. Dopiero całokształt tych regulacji określa sytuację prawną rolnika, w tym zwłaszcza właściciela gospodarstwa rolnego. ${ }^{4}$

Najogólniej rzecz ujmując, wśród uregulowań pozakodeksowych wpływających na wykonywanie prawa własności rolniczej można wyodrębnić takie, które wprawdzie nawiązują bezpośrednio do konstrukcji własnościowej gospodarstwa, gdyż związane są z obrotem gospodarstwami rolnymi, ale zarazem „włączają" mechanizmy administracyjnoprawne, które w istotny sposób wpływają na możliwość „korzystania” przez rolnika z instrumentów wspólnej polityki rolnej. Chodzi tutaj przede wszystkim o umowy zawierane w związku z funkcjonowaniem niektórych wspólnotowych rynków rolnych (przede wszystkim mleka i przetworów mlecznych $)^{5}$.

Drugi kompleks uregulowań prawnorolnych odnoszących się do „korzystania” z prowadzenia gospodarstwa rolnego obejmuje wyłącznie obrót produktami rolnymi na branżowych rynkach rolnych (np. umowy o dostawę mleka w obrocie hurtowym art. 4 ust. $1 \mathrm{w}$ zw. $\mathrm{z}$ art. 10 ust. 2 lit. c, umowy sprzedaży mleka oraz przetworów mlecznych przez dostawcę bezpośredniego - art. 11 oraz umowy zbycia prawa do indywidualnej ilości referencyjnej art. 22 cyt ustawy).

Odrębnym instrumentem korzystania z gospodarstwa rolnego, niezależnie od stosunków własnościowych prowadzącego takie gospodarstwo producenta rolnego, jest konglomerat umów zawieranych w trybie realizacji na rynku rolnym zadań interwencyjnych państwa w ramach prowadzonej wspólnej polityki rolnej ${ }^{6}$.

Korzystanie z nieruchomości rolnych to odrębność regulacji o charakterze administracyjnoprawnym odnoszących się do ochrony gruntów rolnych i leśnych ${ }^{7}$, ochrony przyrody ${ }^{8}$ oraz ochrony środowiska ${ }^{9}$, które najogólniej rzecz ujmując, mają na celu ochronę zasobu gruntów uprawnych niezależnie od tytułu prawnego podmiotu władającego ${ }^{10}$.

4 A. Stelmachowski, Modele własności i ich uwarunkowania społeczno-ustrojowe, (w:) System Prawa Prywatnego, t. 3, red. T. Dybowski, Warszawa 2007, s. 188-189 oraz s. 192-193.

5 Ustawa z 20 kwietnia 2004 r. o organizacji rynku mleka i przetworów mlecznych, Dz.U. z 2009 r., Nr 11, poz. 65 ze zm. Zob. także B. Jeżyńska, Reglamentacja krajowej produkcji rolnej i rejestry produkcji limitowanej, (w:) Prawo rolne, red. P. Czechowski, Warszawa 2011, s. 69 i n. E. Tomkiewicz, Kwoty mleczne jako forma reglamentowania działalności gospodarczej, „Studia luridica Agraria” 2000, t. 1, s.135 i n.

6 P. Czechowski, A. Niewiadomski, Europejskie rynki rolne, (w:) Prawo rolne, red. P. Czechowski, Warszawa 2011, s. 381 in.

Ustawa z dnia 3 lutego 1995 r. o ochronie gruntów rolnych i leśnych Dz.U. z 2004 r. Nr 121, poz. 1266 ze zm. Ustawa z dnia16 kwietnia 2004 r. o ochronie przyrody, Dz.U. z 2009 r. Nr 151, poz. 1220 ze zm. Ustawa z dnia 27 kwietnia 2001 r. Prawo ochrony środowiska, Dz.U. z 2008 r. Nr 25, poz. 150 ze zm.

A. Oleszko, Prawo rolne, Warszawa 2009, s. i n; B. Rakoczy, Ochrona środowiska w procesie produkcji rolnej, (w:) Prawo rolne, red. A. Stelmachowski, Warszawa 2009, s. 357 i n. 
Korzystanie z gospodarstwa rolnego to również możliwość prowadzenia działalności wytwórczej w rolnictwie w zakresie upraw rolnych, chowu i hodowli zwierząt, ogrodnictwa, warzywnictwa, leśnictwa i rybactwa śródlądowego przez podmiot korzystający ze środowiska, ze wszystkimi stąd płynącymi obowiązkami oraz uprawnieniami z tytułu władania gospodarstwem.

Jeżeli działalność gospodarcza nie spowoduje negatywnych skutków dla ochrony gatunków zwierząt, dla których utworzono obszar Natura 2000, to dopuszczalne jest rozpoczęcie takiej inwestycji. Również przepisy o ochronie przyrody pozwalają na prowadzenie na tych obszarach działalności gospodarczej, rolnej, leśnej rybnej i łowieckiej pod warunkiem, że nie wpłynie w istotny negatywny sposób na gatunki zwierząt i roślin ${ }^{11}$.

Pobieranie innych dochodów w ramach korzystania $\mathrm{z}$ gospodarstwa rolnego to przede wszystkim przewidziane przepisami prawa wspólnotowego dopłaty bezpośrednie oraz wspólna polityka cen ${ }^{12}$.

System dopłat bezpośrednich (wsparcia bezpośredniego) stanowi obecnie zasadniczy element wsparcia dochodów w odniesieniu do gospodarstw rolnych w ramach wspólnej polityki rolnej ${ }^{13}$.

Wspólna polityka cen (w szczególności tzw. cen interwencyjnych) ma gwarantować uzyskanie odpowiednich dochodów przez producenta rolnego w sytuacji niewłaściwej sytuacji rynkowej ${ }^{14}$.

\subsection{Społeczno-gospodarcze przeznaczenie gospodarstwa rolnego}

Kolejnym wyznacznikiem granic prawa własności jest klauzula społeczno-gospodarczego przeznaczenia prawa. Spotykamy się także ze szczegółowymi regulacjami kodeksowymi mówiącymi o społeczno-gospodarczym przeznaczeniu gruntu (art. $143 \mathrm{kc}$.) oraz o społeczno-gospodarczym przeznaczeniu nieruchomości (art. 144 kc.). Z kontekstu ustawy wynika, że chodzi tu zawsze o własność samej rzeczy $\mathrm{w}$ rozumieniu art. $45 \mathrm{kc}$.

Omawianą klauzulę odnosimy do gospodarstwa rolnego jako kompleksu praw i obowiązków (mienia zorganizowanego). Podstawowym obowiązkiem właścicie-

11 Zob. z uzasad. wyroku NSA z 4 sierpnia 2009r., II OSK 1239/08, „Rejent” 2009, nr 11, s. 175.

12 Rozporządzenie Rady (WE) nr 73/2009 ustanawiające wspólne zasady dla systemów wsparcia bezpośredniego dla rolników w warunkach wspólnej polityki rolnej i ustanawiające określone systemy wsparcia dla rolników, zmieniające rozporządzenia (WE) nr 1290/2005, (WE) nr 247/2006, (WE) nr 378/2007 oraz uchylające rozporządzenie (WE) nr 1782/2003, Dz. Urz. UE L 30 z 31.01.2009 r., s. 16 ze zm. 13 Ustawa z dnia 26 stycznia 2007 r. o płatnościach w ramach systemów wsparcia bezpośredniego Dz.U. z 2008 r. chowski, Warszawa 2011, s. 407 i n;

14 Por. art. 10-24 rozp. Rady (WE) nr 1234/2007 z dnia 22 października 2007 r. ustanawiającego wspólną organizacje rynków rolnych oraz przepisy szczegółowe dotyczące niektórych produktów rolnych Dz.Urz UE L 299 z 16.11.2007, s. 1-149. oraz ustawę z dnia 11 marca 2004 r. o Agencji Rynku Rolnego i organizacji niektórych rynków rolnych, Dz.U. z 2007 r. Nr 231, poz. 1702 ze zm. 
la jako rolnika jest rolnicze wykorzystanie produkcyjności gospodarstwa w interesie indywidualnym producenta rolnego, kojarzonym $\mathrm{z}$ interesem producenta rolnego $\mathrm{z}$ interesem społecznym. Interes ten jest powszechnie akceptowany na gruncie prawa cywilnego, a swoista ,publicyzacja prawa cywilnego” znajduje szeroki wyraz na gruncie prawa rolnego.

Adresatem klauzuli społeczno-gospodarczego przeznaczenia gospodarstwa rolnego powinien być przede wszystkim ustawodawca. W prawidłowym ukształtowaniu gospodarstw rolnych zaangażowany jest ogólny interes społeczno-gospodarczy, czego wyrazem jest wola ustawodawcy poddawania szczególnym regulacjom z reguły ograniczającym swobodny - poddany regułom rynku i konkurencji - obrót tymi gospodarstwami ${ }^{15}$.

Aktualność powyższej tezy potwierdza wyrok Trybunału Konstytucyjnego z 31 stycznia 2001 r. P 4/99 ${ }^{16}$, który zauważa, że mimo licznych zmian w okresie 1944-1990, ustawodawca nie zrezygnował z odrębnego (szczególnego) uregulowania problematyki gospodarstw rolnych. Zakres swobody ustawodawcy w zakresie ochrony własności rolniczej nie wyklucza regulacji traktującej gospodarstwo rolne jako szczególny przedmiot własności poddany w określonym zakresie pewnym odrębnym regulacjom. Postulatu tego ustawodawca do obecnej pory nie zrealizował.

Klauzula społeczno-gospodarczego przeznaczenia gospodarstwa rolnego znajduje konkretyzację zarówno w uregulowaniach kodeksowych, jak i w ustawach szczególnych. $\mathrm{O}$ ile te pierwsze odnoszą się wprost do gospodarstwa rolnego jako przedmiotu co najmniej mogącego stanowić zorganizowana całość gospodarczą, to uregulowania szczególne przede wszystkim mają na uwadze gospodarcze wykorzystanie gruntów rolnych i leśnych w zapewnieniu zdolności uprawy rolniczej w ramach równowagi przyrodniczo-środowiskowej.

Zgodnie z art. 214 § 1 in fine $\mathrm{kc}$. interes społeczno-gospodarczy stanowić będzie dla sądu kryterium przyznania gospodarstwa rolnego dotychczasowemu współwłaścicielowi. Interes ten będzie bez znaczenia w razie zawarcia umowy zniesienia współwłasności nieruchomości rolnej, gdyż o sposobie wyjścia ze współwłasności decydować będą strony umowy sporządzonej w formie aktu notarialnego. Oznacza to, że decydujący będzie interes indywidualny strony umowy, a nie kryteria wskazane w art. $214 \S 2$ kc., które mają znaczenie tylko w postępowaniu sądowym.

Nabywcą nieruchomości rolnej wchodzącej w skład rodzinnego gospodarstwa rolnego może być tylko rolnik odpowiadający określonym kwalifikacjom ${ }^{17}$. Rów-

A. Stelmachowski, Modele własności i ich uwarunkowania społeczno-ustrojowe, (w:) System Prawa Prywatnego, t. 3, red. T. Dybowski, Warszawa 2007, s. 188-189 oraz s. 192-193.

16 OTK 2001, nr 1, poz. 5.

17 Ustawa z dnia 11 kwietnia 2003 r. o kształtowaniu ustroju rolnego, Dz.U. Nr 64, poz. 592 ze zm. 
nież klauzula społeczno-gospodarczego przeznaczenia gospodarstwa rolnego ma decydować o przeciwdziałaniu nadmiernej koncentracji nieruchomości rolnych.

Przyjęte rozwiązania nie do końca przekonują. Na gruncie prawa rolnego ustawodawca kilkakrotnie i w różnym zakresie wprowadził ograniczenia przedmiotowe oraz podmiotowe obrotu nieruchomościami rolnymi, które nie przyniosły spodziewanych rezultatów w odniesieniu do efektywności społeczno-gospodarczej przeznaczenia własności rolniczej. Można mieć daleko idące wątpliwości, czy obecne restrykcje stan ten zmienią.

Społeczno-gospodarcze przeznaczenie gospodarstwa rolnego to także obowiązek zachowania dobrej kultury rolnej oraz dobrostanu zwierząt. Elementy te mogłyby stać się miernikiem społeczno-gospodarczego przeznaczenia gospodarstwa.

\section{Ustrój rolny a zasady wykładni prawa rolnego}

W literaturze przedmiotu tradycyjnie regulacje prawnorolne traktowane są jako pogranicze prawa publicznego oraz prawa prywatnego. Zgodnie podkreśla się, że dotychczas nie zostały wyraźnie wykształcone normy prawne charakterystyczne wyłącznie dla prawa rolnego jako sposobu regulacji tego działu (gałęzi) prawa, przy równoczesnym wyraźnym i niebudzącym wątpliwości funkcjonalnym wyodrębnieniem prawa rolnego $\mathrm{w}$ ramach systemu prawa ${ }^{18}$.

U podstaw ustroju rolnego tkwią stosunki własnościowe ziemi uprawnej, która stanowi pierwszy i nieodzowny łańcuch żywnościowy. Z kolei podstawowym atrybutem prawa własności, a tym bardziej własności rolniczej jest uprawnienie do korzystania z gospodarstwa rolnego, które w środowiskach wiejskich stanowi nadal poważny problem natury społecznej ${ }^{19}$.

Obecne zmiany ustrojowe rolnictwa nie są pierwszymi. Instytucjonalne rozwiązania zapoczątkowane zostały bowiem reformą rolną z 1944 r. ${ }^{20}$ oraz po 1989 r. $^{21}$ Każda z tych reform rolnych spowodowała gruntowne zmiany własnościowe gospodarstw rolnych nie tylko w wymiarze gruntowym, ale także i produkcyjnym.

Cechą współczesnego rolnictwa jest mimo wszystko nadal nieuporządkowany stan własnościowy nieruchomości rolnych, którego formalnie obowiązujące źródła prawa pochodzą jeszcze sprzed 1990 r., a nawet z okresu reformy rolnej i w żadnej

A. Lichorowicz, Pojęcie i przedmiot prawa rolnego, (w:) Prawo rolne, pod red. A. Stelmachowskiego, Warszawa 2009, s. 23 i n.; R. Budzinowski, Pojęcie i przedmiot prawa rolnego, (w:) Prawo rolne, pod red. P. Czechowskiego, Warszawa 2011, s. 23 i n.; tenże, Problemy ogólne prawa rolnego. Przemiany podstaw legislacyjnych i koncepcji doktrynalnych, Poznań 2008, s. 106 i n.

19 Por. uzasad. uchwały SN składu siedmiu sędziów SN z dnia 25 listopada 2005 r., III CZP 59/05, OSNC 2006, nr 5, poz. 79.

20 Dekret z dnia 6 września 1944 r. o przeprowadzeniu reformy rolnej. Dz.U. z 1945 r. Nr 3, poz. 13 ze zm., dalej jako dekret z $1944 \mathrm{r}$.

21 Ustawa z 28 lipca 1990 r. o zmianie ustawy - Kodeks cywilny, Dz.U. Nr 55, poz. 321. 
mierze nie odpowiadają współczesnym standardom konstytucyjnego państwa prawa. Wskazać tu choćby wystarczy na nadal trwający problem tzw. uwłaszczenia gospodarstw rolnych wywołany nieformalnym obrotem nieruchomościami rolnymi i stanem samoistnego posiadania ocenianym na dzień 4 listopada $1971 \mathrm{r}^{22}$ Mimo upływu 40 lat sądy nadal orzekają o stwierdzeniu nabycia własności nieruchomości rolnej w trybie uwłaszczenia według stanu prawnego na dzień 4 listopada 1971 r.

W konsekwencji dokonanych przemian po 1990 r. z jednej strony doszło do całkowitego liberalizmu obrotu inter vivos, a z drugiej przepisy o dziedziczeniu gospodarstw rolnych są obecnie stosowane w kilku różnych wersjach w zależności od tego, kiedy nastapiło otwarcie $\mathrm{spadku}^{23}$. Nadal pozostaje niezrealizowane zalecenie Trybunału Konstytucyjnego uporządkowania ustawodawstwa rolnego zgodnie z konstytucyjnymi wymogami ochrony własności oraz dziedziczenia ${ }^{24}$.

Skomplikowany stan prawny w zakresie szeroko rozumianych stosunków własnościowych inter vivos, jak również mortis causa nie ułatwia jego stosowania. Tym bardziej istotną rolę ogrywa wykładnia norm prawnorolnych.

Dokonując oceny źródeł prawa odnośnie do dekretów wydanych w związku z przeprowadzeniem reformy rolnej nadal obowiązujących bądź które utraciły moc prawną, Trybunał Konstytucyjny uznał, że ,ustawami w rozumieniu art. 33a „małej" Konstytucji oraz art. 1, 5 i 13 ustawy z dnia 29 kwietnia 1985 r. o Trybunale Konstytucyjnym są także akty prawotwórcze niebędące ustawami w znaczeniu formalnym, ale mające rangę równą ustawie (dekrety z mocą ustawy) w hierarchii źródeł prawa. Konstytucja nie zna instytucji dekretu z mocą ustawy, to jednak wobec obowiązywania dekretów ustanowionych wcześniej przez kompetentne organy, które na mocy wówczas obowiązujących przepisów prawa określane były jako dekrety z mocą ustawy, podlegają wykładni Trybunału Konstytucyjnego ${ }^{25}$.

Dopuszczenie do wykładni powyższych dekretów nie oznacza ich legalności ani tym bardziej oceny zgodności tych dekretów z obecnie obowiązującymi normami konstytucyjnymi. Ocena suwerenności i legalności Polskiego Komitetu Wyzwolenia Narodowego jako polskiego prawodawcy należy do współczesnego, demokratycznego ustrojodawcy.

W dotychczasowym orzecznictwie Trybunału Konstytucyjnego wielokrotnie dominował pogląd, że formalne uchylenie czy zmiana przepisu nie zawsze oznacza

22 Ustawę z dnia 26 października 1971 r. o uregulowaniu własności gospodarstw rolnych, Dz.U. Nr 27, poz. 250 ze $\mathrm{zm}$.

23 Zob. przypis 15.

24 Zob. przypis 14. Zob. także A. Stelmachowski, Współczesne zróżnicowanie własności, „Studia luridica Agraria” 2002, t. 3, s. 15 i n.; T. Kurowska, Współczesne aspekty własności rolniczej, s. 39 i n. 1995 r., W 9/94, OTK 1995 cz. 1/2 oraz krytyczna glosę P. Winczorka, „Państwo i Prawo” 1995, nr 9, s. 106 i n.; uchwałę TK z 16 kwietnia 1996 r. W 15/95, OTK 1996, nr 2, poz. 13. 
zupełną utratę mocy obowiązującej wyrażonych w nim norm prawnych. W szczególności w tym sensie, że za przepis zachowujący moc obowiązującą należy uznać taki przepis, który chociaż został formalnie derogowany, to nadal ma zastosowanie do ustalenia skutków zdarzeń zaistniałych w czasie, w którym ten przepis obowiązywał. W takiej sytuacji nie powinno być wątpliwości dotyczących dopuszczalności dokonywania przez Trybunał Konstytucyjny powszechnie obowiązującej wykładni przepisu, który jeszcze może mieć zastosowanie do ustalenia skutków zdarzeń zaistniałych w przeszłości, a przy tym nie został wyraźnie derogowany przez ustawodawcę ${ }^{26}$.

O przejęciu nieruchomości na własność Skarbu Państwa orzekał decyzją administracyjną ówczesny organ administracji państwowej, stosownie do uchwały Trybunału Konstytucyjnego z 20 lutego 1991 r. W 5/90, bez względu na okoliczności, w jakich doszło do objęcia nieruchomości przez Skarb Państwa. Oznacza to, iż przejęciu na własność Skarbu Państwa podlegały nieruchomości, których właściciele do dnia 5 kwietnia 1958 r. dawali wyraz woli odzyskania swej nieruchomości, względnie z przyczyn obiektywnych, od siebie niezależnych, nie mieli możliwości dochodzenia swoich praw.

Do końca lat osiemdziesiątych w orzecznictwie, a także w literaturze dominował kierunek wykładni regulacji prawnych związanych z przeprowadzeniem reformy rolnej i osadnictwa przypisujący wyłącznie kompetencje organom administracji państwowej w zmianie stosunków własnościowych (prawnorolnych) bez jakiejkolwiek w tym zakresie możliwości kontroli sądów powszechnych ${ }^{27}$.

W orzecznictwie Sądu Najwyższego podkreśla się, że dotychczasowa interpretacja przepisów o przeprowadzeniu reformy rolnej, nielicząca się z ich treścią, podyktowana była przesłankami politycznymi i nie jest obecnie do utrzymania. Aktualny właściciel bądź jego następca prawny ma interes prawny w twierdzeniu, że dokonany wpis w księdze wieczystej ujawniający jako właściciela Skarb Państwa jest niezgodny z rzeczywistym stanem prawnym, a przejęta nieruchomość nie podlegała regulacjom z dekretu z 1944 bądź z 1946 r. W takich wypadkach zachodzi typowy spór o prawo własności, którego rozstrzygnięcie należy do sądu ${ }^{28}$.

Dokonując wykładni dekretu z 1944 r. a zwłaszcza przepisu art. 2 ust. 1 lit. e przepisu, Trybunał Konstytucyjny wskazał, że skutki własnościowe zostały skonsumowane jednorazowo z chwilą jego wejścia w życie, tj. w dniu 13 września 1944 r. w warunkach ustrojowych oraz historycznych należących już do przeszłości i by-

26 Uchwała TK z 16 kwietnia 1996 r., W 15/95, OTK 1996, nr 2, poz. 13; B. Wierzbowski, Akty normatywne kształtujące ustrój rolny w orzecznictwie Trybunału Konstytucyjnego, „Studia luridica Agraria” 2002, t. 3, s. 181 i n.

27 W szczególności zob. uchwałę składu siedmiu sędziów SN z 13 października 1951 r., C 427/51, OSN 1953, nr 1, poz. 1.

28 Uchwała SN z 27 września 1991 r., III CZP 90/91, OSNC 1992, nr 5, poz. 72; uchwała SN z 27 kwietnia 1994 r., III CZP 54/94, OSNC 1994, nr 11, poz. 215; wyrok SN z 8 maja 1998 r. I CKN 664/97, OSNC 1999, nr 1, poz. 7. 
łyby nie do pogodzenia z obecnymi zasadami ustrojowymi. Nie ma podstaw prawnych do „rozciągania” w czasie (pro futuro) stosowania skutku prawnorzeczowego art. 2 ust. 1 lit. e cyt. dekretu w postaci przejęcia na własność Skarbu Państwa określonych w nim nieruchomości poza dzień wejścia w życie omawianego dekretu ${ }^{29}$.

Oznacza to również, że w trybie dekretów z 1944 oraz 1946 r. ${ }^{30}$ nie można obecnie żądać nadania nieruchomości rolnej na rzecz rolników formalnie uprawnionych do skorzystania z reformy, którym odmówiono prawa własności ziemi z przyczyn politycznych. Takie rozciągnięcie w czasie reformy rolnej, wywołujące wciąż na nowo skutki własnościowe, byłoby niedopuszczalne również ze względu na zasady demokratycznego państwa prawa i ochrony własności czy chociażby generalny brak możliwości przypisania współczesnemu prawodawcy wartości i preferencji właściwych autorom dekretu o reformie rolnej.

Formalne uchylenie aktu prawnego (dekretu) pozostającego w związku z przeprowadzeniem reformy rolnej nie zamyka obecnie osobie uprawnionej drogi sądowej w razie sporu co do prawa własności bezprawnie przejętej nieruchomości rolnej.

W ramach szerszego pojęcia ustroju gospodarczego znajdujemy węższe określenie ustroju rolnego. Dotychczas w doktrynie prawa rolnego ustrój rolny określano jako „układ stosunków własnościowych i form organizacji produkcji w rolnictwie, jak również form organizacji rynku rolnego".

Natomiast art. 23 Konstytucji przesądza, że podstawową formą organizacyjną ustroju rolnego jest gospodarstwo rodzinne, a więc takie, w którym działalność gospodarcza jest sprzężona z rodziną. Nie określa on miejsca rolnictwa w systemie gospodarki narodowej, nie określa też celów i przemian ustrojowych, nie precyzuje środków, przy pomocy których ma być realizowana ta zasada. Zawiera tylko jedną dyspozycję o charakterze ustrojowym. ${ }^{31}$

Odrębność własności rolniczej w płaszczyźnie funkcjonalnej istniała zawsze ${ }^{32}$. Trudno negować charakter produkcji rolnej, której istotnym elementem jest wykorzystanie ziemi jako niezbędnego środka produkcji. Niezależnie od innych czynni-

W szczególności zob. uchwałę TK z 16 kwietnia 1996 r. W 15/95, OTK 1996, nr 2, poz. 213.

Dekret z 6 września 1946 r. o ustroju rolnym i osadnictwie na obszarze Ziem Odzyskanych i byłego Wolnego Miasta Gdańska Dz.U. Nr 49, poz. 279; Z. Truszkiewicz, Kształtowanie stosunków własnościowych w rolnictwie, (w:) Prawo rolne, red. P. Czechowski, Warszawa 2011, s. 147 i n.

31 K. Stefańska, Gospodarstwo rodzinne jako element ustroju rolnego, „Studia luridica Agraria” 2002, t. 3, s. 171 in.

32 W warunkach polskich wywodzi się ona z dawnej własności wiejskiej, czego aktualnym wyrazem jest art. 48 ust. 3 ustawy z dnia 8 marca 1990 r. o samorządzie gminnym (Dz.U. z 2001 r. Nr 142, poz. 1591 ze zm.), według którego „wszystkie przysługujące dotychczas mieszkańcom wsi prawa własności, użytkowania lub inne prawa rzeczowe i majątkowe zwane dalej mieniem gminnym pozostają nienaruszone". Nie mniej aktualne są uregulowania ustawy z dnia 29 czerwca 1963 r. o zagospodarowaniu wspólnot gruntowych (Dz.U. Nr 28, poz. 169 ze zm.), które utrzymują byt prawny dawnych wspólnot gruntowych jako specyficznych jednostek własnościowych związanych z uwłaszczeniem chłopów w poszczególnych zaborach. Do dzisiaj istnieja odrębne regulacje własnościowe na wydzielanych wspólnotach gruntowych, na których dominowała własność wspólna uznawana na 
ków ekonomicznych i organizacyjnych ziemia pozostaje nadal podstawowym czynnikiem produkcji rolniczej, co wpływa na zwiększenie znaczenia własności rolniczej określanej także jako własność gruntowa. ${ }^{33}$

Własność rolnicza jest związana z gospodarstwem rolnym rozumianym jako czynna masa majątkowa (bez pasywów), a w ujęciu cywilistycznym jako mienie.

Dla treści prawa własności oprócz rzeczy jako punktu odniesienia tego prawa istotne znaczenie ma zarówno mienie, jak i majątek. O ile mienie określone w art. 44 kc. jest zbiorczą nazwą dla ogółu przedmiotowych praw majątkowych cywilnych oraz pozostałych, to problem majątku jest bardziej teoretycznie złożony.

Trudność ta polega na tym, że w naszym prawie masy majątkowe stanowią kompleksy niejednorodne. $\mathrm{W}$ ich ramach występują także zorganizowane masy majątkowe, do których kodeks cywilny m.in. zalicza gospodarstwo rolne (art. 553).

Majątek, zgodnie z utrwalonym w doktrynie poglądem, to ogół aktywów majątkowych przysługujących określonemu podmiotowi. W znaczeniu szerszym dodaje się także ogół pasywów. W tym zakresie gospodarstwo rolne winno być ujmowane jako masa majątkowa składająca się z aktywów, które stanowią lub mogą stanowić zorganizowaną masę majątkową. W skład tak rozumianego gospodarstwa rolnego wchodzą prawa związane z prowadzeniem gospodarstwa rolnego. Pojęcie gospodarstwa jako masy majątkowej stwarza z jednej strony zespół praw determinujących wykonywanie własności, a z drugiej strony jest niezbędnym elementem, wokół którego ogniskują również zasady prawa rolnego. ${ }^{34}$

Również rola i charakter poszczególnych składników majątkowych gospodarstwa rolnego nie jest ani jednakowa, ani tym bardziej niezmienna.

W doktrynie powszechnie przyjmuje się, że niezależnie od różnych mas majątkowych składających się na cywilnoprawne pojecie gospodarstwa rolnego, gospodarstwo to jako masa majątkowa może być przedmiotem obrotu jako całość (inter vivos co do gospodarstwa rolnego oraz mortis causa jako przedmiot spadku). ${ }^{35}$ To ta masa majątkowa podlega obrotowi i zapewnia niepodzielność zbywanych całości. Jest to pewna konstrukcja o charakterze teoretycznym. Obrót inter vivos nie odbywa się się na zasadzie „obrotu” masy majątkowej w postaci gospodarstwa rolnego, tylko przedmiotem tego obrotu jest zawsze nieruchomość rolna oznaczona jako

podstawie nadań królewskich czy wielkich właścicieli należących do Zamoyskich. W ramach utworzonego Tatrzańskiego Parku Narodowego „ocalała” dawna Witowska Wspólnota Ośmiu Wsi. go, t. 3, red. T. Dybowski, Warszawa 2007, s. 178.

34 P. Czechowski, A. Niewiadomski, Gospodarstwo rolne jako masa majątkowa, „Studia luridica Agraria”, Białystok 2009, t. 8, s. 47 in. 35 A. Stelmachowski, Modele własności i ich uwarunkowania społeczno-ustrojowe, (w:) System Prawa Prywatne-
go, t. 3, red. T. Dybowski, Warszawa 2007, s. 178 
działka rolna ${ }^{36}$ wchodząca w skład gospodarstwa rolnego. Jednakże - co wymaga jednoznacznego podkreślenia - przedmiotem obrotu mogą być tylko poszczególne składniki gospodarstwa wyszczególnione w treści umowy sporządzonej w formie aktu notarialnego.

Inaczej konstrukcja „masy” gospodarstwa rolnego kształtuje się w razie dziedziczenia (ustawowego oraz testamentowego). Zgodnie z art. $677 \mathrm{kpc}$. oraz art. $95 \mathrm{f}$ $\S 1$ pkt 7 Prawa o notariacie ${ }^{37}$, sąd w postępowaniu o stwierdzenie nabycia spadku oraz notariusz w zarejestrowanym akcie poświadczenia dziedziczenia wymieniają w tych dokumentach osobę (osoby) jako spadkobierców oraz ułamek, w którym dziedziczą gospodarstwo rolne co do spadków otwartych przed 14 lutego $2001 \mathrm{r}$. (w wypadku dziedziczenia ustawowego), a przed 1 października 1990 r. (co do dziedziczenia testamentowego).

Po tych datach otwarcia spadku wyodrębnienie gospodarstwa jako odrębnej masy majątkowej nie istnieje. ${ }^{38}$

Funkcjonalne wyodrębnienie własności rolniczej odnosi się także do pojęcia nieruchomości rolnej, wchodzącej w skład gospodarstwa rolnego jako przedmiotu szczególnego obrotu (art. $46^{1} \mathrm{~W}$ zW. z art. $155 \S 1$ i art. $353 \S 1$ kc. oraz art. 2 pkt 1 w zw. z art. 3 i 4 ustawy z dnia 11 kwietnia 2003 r. o kształtowaniu ustroju rolnego). ${ }^{39}$

O istnieniu gospodarstwa rolnego decydują grunty rolne, o których stanowi art. $46^{1}$ kc., są koniecznym i niezbędnym jego składnikiem. ${ }^{40}$

W piśmiennictwie wskazuje się, że z faktu, że własność rolnicza odnosi się do mienia, w istocie stanowi kompleks praw i obowiązków.

Wspomniane obowiązki odnoszą się nie tylko do właściciela (np. w obszarze prawa sąsiedzkiego), ale przede wszystkim wobec państwa reprezentującego interes społeczeństwa jako całości. W zamian za należyte wykonywanie własności rolniczej właściciel ma prawo liczyć na pomoc przy wykonywaniu swego prawa własności, zwłaszcza gdy chodzi o podejmowanie przedsięwzięć, które przekraczają możliwości działania rolnika jako jednostki. ${ }^{41}$

Rozporządzenie Ministra Rozwoju Regionalnego i Budownictwa z dnia 29 marca 2001 r. w sprawie ewidencji gruntów i budynków, Dz.U. Nr 38, poz. 454.

37 Zob. ustawa z 24 lutego 1991 r. Prawo o notariacie, Dz.U. z 2008 r. Nr 189, poz. 1158 ze zm.

38 Z. Truszkiewicz, Dziedziczenie gospodarstw rolnych, (w:) Prawo rolne, red. P. Czechowski, Warszawa 2011, s. 224 in

39 Dz.U. Nr 64 poz. 592 ze zm.

40 Por. post. SN z dnia 7 maja 1997 r. II CKN 197/97, „Wokanda” 1997, nr 9, s. 9 oraz wyrok NSA z dnia 20 września 1991 r., II SA 669/91, ONSA 1992, nr 2, poz. 26.

41 Zob. A. Stelmachowski, Modele własności i ich uwarunkowania społeczno-ustrojowe, (w:) System prawa prywatnego, red. T. Dybowski, Warszawa 2007, t. 3, s. 189. 
Do wskazanych przedsięwzięć ze strony państwa należą m.in. melioracje wodne, których wykonanie i utrzymanie, w zakresie urządzeń melioracji podstawowych należy do obowiązków państwa. Urządzenia te stanowią również jego własność. Państwo może ponosić także koszty związane z urządzeniami melioracji szczegółowych, gdy teren objęty melioracjami obejmuje rozdrobnione gospodarstwa rolne, istniejącym już urządzeniom grozi dekapitalizacja lub jeżeli warunkiem restrukturyzacji rolnictwa jest regulacja stosunków wodnych. ${ }^{42}$

W ramach gospodarki wodnej osobnym przedsięwzięciem państwa jest zaopatrzenie wsi w wodę. ${ }^{43}$

Scalanie i wymiana gruntów jest klasycznym rozwiązaniem w celu tworzenia korzystnych warunków gospodarowania w rolnictwie oraz poprawy struktury obszarowej gospodarstw rolnych. Postępowanie scaleniowe lub wymienne przeprowadza starosta ze środków budżetu państwa z pewnymi zastrzeżeniami. ${ }^{44}$

Przepisy ustawy z dnia 27 marca 2003 r. o planowaniu i zagospodarowaniu przestrzennym ${ }^{45}$ określają zasady kształtowania polityki przestrzennej, a także zakres i sposoby postępowania w sprawach przeznaczenia terenów na określone cele. W planowaniu przestrzennym uwzględnia się zwłaszcza m.in. wymagania ochrony gruntów rolnych i leśnych (art. 1 ust. 2). Jest to typowy obowiązek publicznoprawny należący do państwa, a odstępstwa od tej zasady muszą mieć charakter proporcjonalny w stosunku do celów i zadań państwa i wynikać wprost z ustawy ${ }^{46}$.

Ochrona gruntów rolnych i leśnych jest obowiązkiem nie tylko właściciela gruntu, ale również posiadacza samoistnego, zarządcy lub użytkownika, dzierżawcy oraz użytkownika wieczystego ${ }^{47}$. Artykuł 5 ust. 5 cyt. ustawy nakłada na starostę ogólną kompetencję w sprawach ochrony gruntów rolnych oraz na dyrektora regionalnej dyrekcji Lasów Państwowych - w zakresie gruntów leśnych.

Odrębność funkcjonalna rolnictwa znalazła najszerszy wyraz w postaci interwencjonizmu publicznego z chwilą uzyskania członkostwa Polski w Unii Europejskiej (UE) i związane $\mathrm{z}$ tym znamienne przesunięcie akcentów w kierunku wspólnotowych środków pomocowych, które można określić jako odchodzenie od tradycyjnej polityki rolnej na rzecz polityki rozwoju obszarów wiejskich.

J. Szachułowicz, Melioracje wodne, (w:) Prawo rolne, red. A. Stelmachowski, Warszawa 2009, s. 503-507.

J. Szachułowicz, Zaopatrzenie wsi w wodę, (w:) Prawo rolne, red. A. Stelmachowski, Warszawa 2009, s. 508510.

A. Zieliński, Scalanie i wymiana gruntów, (w:) Prawo rolne, red. A .Stelmachowski, Warszawa 2009, s. 262 i n. Zob także B. Wierzbowski, Kształtowanie ustroju rolnego. Aspekty przestrzenne, „Studia luridica Agraria” 2005, t. 5 , s. 233 in.

Dz.U. Nr 80, poz. 717 ze zm.

Por. wyrok TK z dnia 6 czerwca 2006r. K 23/05, OTK ZU 2006, nr 6A, poz. 62; zob. także T. Kurowska, Miejscowy plan zagospodarowania przestrzennego a prawo własności, „Studia luridica Agraria” 2005, t. 5, s. 113 i n. Ustawa z dnia 3 lutego 1995r. o ochronie gruntów rolnych i leśnych (Dz.U. z 2004 r. Nr 121, poz. 1266 ze zm). 
Polityka rozwoju obszarów wiejskich wyznacza nowy kształt rolnictwa - zarówno jako sektora gospodarki, jak i w sferze pozaprodukcyjnej (tzw. rolnictwa wielofunkcyjnego).

Cele wskazanej polityki zmierzają w trzech kierunkach: poprawy konkurencyjności rolnictwa i leśnictwa, poprawy środowiska naturalnego i terenów wiejskich przez wspieranie gospodarowania gruntami oraz poprawy jakości życia na obszarach wiejskich i dywersyfikacji działalności gospodarczej.

Realizacja wskazanych założeń następuje w drodze instytucji prawnych właściwych jedynie sektorowi rolnemu.

Polityka strukturalna w odniesieniu do obszarów wiejskich ma odrębne podstawy prawne od „ogólnej” polityki spójności UE, co stanowi wyraźny dowód na uwzględnienie przez wspólnotowego prawodawcę specyfiki oraz odrębności rolni$\operatorname{ctwa}^{48}$.

Odrębność funkcjonalna własności rolniczej jako „zorganizowanej całości gospodarczej”, czy też związana z „prowadzeniem gospodarstwa” znajduje wyraz nie tylko w „regulacjach własnościowych”, ale w coraz szerszym zakresie stanowi przejaw „działalności rolniczej” podejmowanej przez „osobę fizyczną lub prawną lub grupę osób fizycznych lub prawnych, bez względu na status prawny takiej grupy i jej członków w świetle prawa krajowego, której gospodarstwo znajduje się na terytorium Wspólnoty ${ }^{49}$.

48 Rozporządzenie Rady (WE) nr 198/2005 z dnia 20 września 2005 r. w sprawie wsparcia rozwoju obszarów wiejskich przez Europejski Fundusz Rolny na rzecz Rozwoju Obszarów Wiejskich (EFRROW) Dz.Urz. UE L 277 z 21.10.2005, s. $1-40$.

49 Por. art 2 lit. a rozporządzenia Rady (WE) nr 73/2009 z dnia 19 stycznia 2009 r. ustanawiającego wspólne zasady dla systemów wsparcia bezpośredniego dla rolników w ramach wspólnej polityki rolnej i ustanawiające określone systemy wsparcia dla rolników Dz.Urz. UE L 30 z 31.1.2009, s. 16-99. 


\section{The importance of agricultural real estate in the development of agricultural systems}

Key words: agricultural production, agricultural property, right to farm

Agricultural real estate has always been a separate element in the functional plane. While assessing the character of agricultural production systems, it is important to pay attention to land use which can be defined as an essential means of production in the agricultural sector. Regardless of economic and organizational factors, land still remains a crucial component in agricultural production, which increases the importance of agricultural real estate. The fundamental attribute of ownership, especially in agricultural property rights, is a right to farm. Agricultural real estate is associated with farming which is understood as assets of the estate and stands for property in terms of civil law. Functional separation of agricultural real estate also relates to the concept of agricultural property which is a part of farming. Agricultural real estate refers to property and constitutes a set of rights and obligations. 